\title{
Nutritional Status Might Be Related to Physical Performance and Functionality in Older Adults
}

\author{
Yaşlı Bireylerde Nütrisyonel Durum Fiziksel Performans ve Fonksiyonellikle İlişkili Olabilmektedir
}

${ }^{1}$ Department of Geriatric Medicine, Tepecik Education and Research Hospital, Izmir, Turkey

${ }^{2}$ Department of Geriatric Medicine, Sivas State Hospital, Sivas, Turkey

${ }^{3}$ Unit for Aging Brain and Dementia, Department of Geriatric Medicine, Faculty of Medicine, Dokuz Eylul University, Izmir Turkey

Correspondence:

Suleyman Emre KOCYIGIT

Department of Geriatric Medicine,

Tepecik Training and Research

Hospital, Izmir, Turkey

e-mail: suleymanemrekocyigit@

gmail.com
${ }^{1}$ Suleyman Emre Kocyigit, ${ }^{2}$ Ali Ekrem Aydin, ${ }^{3}$ Ahmet Turan Isik

\section{Abstract}

It was aimed to investigate the effect of malnutrition with and the risk of malnutrition in elderly individuals with regards to other geriatric syndromes and comprehensive geriatric assessment (CGA) parameters. Patients who applied to the geriatric outpatient clinic between January 2019 and June 2020 were included in the study. 460 patients were examined. The patients were divided into three groups according to malnutrition, malnutrition-risk, and normal nutritional status. These three groups were compared in terms of geriatric syndromes and CGA parameters. The well-nourished group and the risk of malnutrition and malnutrition group were compared in terms of geriatric syndromes and CGA parameters adjusted for age and gender. Of 460 patients, $64.5 \%$ of these patients were female, and the mean age was $77.75 \pm 8.12,65$ had malnutrition, and 141 had malnutrition-risk. When the well-nourished group was compared with the malnutrition and malnutrition-risk group, age, education year, frequency of cerebrovascular disease were statistically different. The frequency of falls, dementia, sleep disturbance, urinary incontinence, orthostatic hypotension, polypharmacy, sarcopenia, and frailty was higher in groups with malnutrition and malnutrition-risk than in the normal group $(\mathrm{p}<0.05)$. Also, activities of daily living (ADLs) and gait and balance scores were lower in the group with malnutrition and malnutrition risk $(\mathrm{p}<0.05)$. In the regression analysis adjusted for age and gender, geriatric depression, urinary incontinence, dementia orthostatic hypotension, sarcopenia, and frailty were increased in the group with malnutrition and malnutrition risk compared to the normal group $(\mathrm{p}<0.05)$. Malnutrition and risk of malnutrition is associated with other geriatric syndromes and deterioration in ADLs. Therefore, nutritional evaluation must be included in the assessment of older adults, and necessary interventions should be made to optimize the nutritional status.

Keywords: Malnutrition; geriatric syndrome; comprehensive geriatric assessment

\section{Özet}

Yaşlı bireylerde malnütrisyon ve malnütrisyon riskinin etkisinin, diğer geriatrik sendrom ve ayrıntılı geriatrik değerlendirme (AGD) parametreleri açısından araștırılması amaçlandı. Ocak 2019-Haziran 2020 tarihleri arasında geriatri polikliniğine bașvuran hastalar çalışmaya dahil edildi. 460 hasta değerlendirildi. Hastalar malnütrisyon, malnütrisyon-riski ve normal beslenme açısından üç gruba ayrıldı. Bu üç grup geriatrik sendromlar ve AGD parametreleri açısından karşlaş̧ırıldı. Normal beslenen grup ile malnütrisyon riski ve malnütrisyon grubu, yas ve cinsiyete göre düzeltme yapılarak, geriatrik sendromlar ve AGD parametreleri açısından değerlendirildi. 460 hastanın\% 64,5'i kadın olup, ortalama yaş 77,75 $\pm 8,12$ olarak izlendi ve bu hastaların $65^{\prime}$ inde malnütrisyon ve 141 'inin malnütrisyon riski mevcuttu. Normal beslenme durumuna sahip grup, malnütrisyon ve malnütrisyon risk grubu ile karssılaștırıldığında yas, eğitim yllı, serebrovasküler hastalık sıklığı istatistiksel olarak farklıydı. Düsme, demans, uyku bozukluğu, üriner inkontinans, ortostatik hipotansiyon, polifarmasi, sarkopeni ve kırılganlık sıklığı malnütrisyon ve malnütrisyon riski olan gruplarda normal gruba göre daha yüksekti $(\mathrm{p}<0.05)$. Ayrıca, günlük yaşam aktiviteleri (GYA) ile yürüme ve denge skorları malnütrisyon ve malnütrisyon riski olan grupta daha düșüktü $(\mathrm{p}<0.05)$. Yaș ve cinsiyete göre düzeltilmis regresyon analizinde, geriatrik depresyon, üriner inkontinans, demans, ortostatik hipotansiyon, sarkopeni ve kırılganlık normal gruba göre, malnütrisyon ve malnütrisyon riski olan grupta daha yüksek gözlendi $(\mathrm{p}<0.05)$. Malnütrisyon ve malnütrisyon riski, diğer geriatrik sendromlar ve GYA'larda bozulma ile ilişkilidir. Bu nedenle, nütrisyonel değerlendirme yaşlı erişkinlerin değerlendirmesinde yer almalı ve beslenme durumunu optimize etmek için gerekli müdahaleler yapılmalıdır.

Anahtar Kelimeler: Malnütrisyon; geriatrik sendrom; ayrıntılı geriatrik değerlendirme 


\section{Introduction}

Older adults constitute a mentionable part of society and include the most significant hospital admissions due to prolonged life span (1). However, evaluating older people becomes more complicated due to accompanying medical, functional, physiological, and social impacts. Comprehensive geriatric assessment (CGA) is the essential element of modern geriatric care. It is defined as a multi-dimensional and interdisciplinary diagnostic process focused on determining the medical, psychological, and functional abilities of older adults in order to develop a coordinated and integrated plan for treatment and long-term follow-up (2). CGA, which is involved in both the diagnosis and treatment process, has been accepted as the primary method in evaluating geriatric cases, and the broader assessment of geriatric syndromes is provided with CGA.

Malnutrition, which is common in the elderly population, is an important and serious condition. The prevalence of malnutrition is $5-10 \%$ in the community-dwelling older adults, $30-61 \%$ in hospitalized older people, and $12-85 \%$ in the elderly living in a nursing home (3). Malnutrition, which is an essential geriatric syndrome, also leads to many undesirable consequences such as delayed immune response, increased risk of infection, sarcopenia, and frailty, delayed wound healing and the risk of pressure injury, falls, and increased risk of hip fracture (4). Malnutrition is a remarkable geriatric condition that causes increased morbidity and mortality. Besides, malnutrition is also associated with increased mortality regardless of the cause (5). Nutritional status should be checked in older adults every visit under CGA. Therefore, malnutrition risk should be detected early in geriatric practice. Mini nutritional assessment (MNA) was developed as a reliable screening test to determine malnutrition and detect the risk of malnutrition on early period in older adults. The nutritional status of the patients can be easily predicted with questions and anthropometric measurement (6). In the literature, studies examining malnutrition and its relationship with other geriatric syndromes together on the basis of CGA are quite limited. It was determined that a low MNA score was associated with depression, dementia, functional dependence, and multiple co-morbidities in a recent study (7). Sarcopenia is one of the geriatric syndromes whose relationship with malnutrition has been investigated most frequently in the literature. However, it is not clear whether this relationship is dependent on age and gender or not. In addition, it remains unclear the relationship between the risk of malnutrition and other geriatric syndrome.

It was aimed to examine the relationship between malnutrition and the risk of malnutrition with other geriatric syndromes in patients over 65 years of age who applied to our outpatient clinic by age and genderadjusted in the present study.

\section{Material and Method}

\section{Study Design}

This retrospective and cross-sectional observational study included 460 older adults admitted to the geriatrics clinic at Dokuz Eylul University Hospital between January 2019 and June 2020. After obtaining informed written consent from the geriatric patients, a CGA was performed on all participants.

\section{Inclusion Criteria}

Patients over 65 years of age who were admitted to our outpatient clinic for any reason, and had none of the exclusion criteria, were included in this study.

\section{Exclusion Criteria}

Patients with severe anemia (hemoglobin $<10$ $\mathrm{g} / \mathrm{dL}$ ), critical mitral and/or aortic valve stenosis, acute or chronic renal insufficiency (estimated Glomerular Filtration Rate (eGFR) $<40 \mathrm{~mL} / \mathrm{min} / 1.73 \mathrm{~m}^{2}$ ), decompensated cardiac and/or hepatic insufficiency, severe carotid artery stenosis and/or coronary artery stenosis, myocardial infarction or lower extremity fracture in the past week, acute cerebrovascular event in the past month, hypotensive shock, bradycardia or tachycardia during the examination, dehydration, 
electrolyte imbalance, acute hemorrhage, severe metabolic acidosis, sepsis, and similar severe comorbid conditions, immobility due to severe osteoarthritis or neuromuscular disease, and delirium, oropharyngeal dysphagia, alcohol, and drug abuse were excluded.

\section{Patient Characteristics}

Demographic data (age, gender, and education year) and comorbidities including hypertension, diabetes mellitus, coronary artery disease, congestive heart disease, peripheral vascular disease, chronic obstructive pulmonary disease, cerebrovascular disease, hyperlipidemia were reported. The presence of falls in a recent year, urinary incontinence (UI), sleep disorder, depression, orthostatic hypotension $(\mathrm{OH})$, sarcopenia, frailty, polypharmacy, dementia was obtained from hospital records. The diagnosis of geriatric depression and dementia was made by the diagnostic and statistical manual of mental disorders fifth edition (DSM-5) criteria. The active standing test was performed for the diagnosis of orthostatic hypotension. The first blood pressure measurement was taken following 5 min of rest at the lying position; afterward, the patient was raised upright, and the measure was repeated on the same arm, at the 3rd minute, using a mercury sphygmomanometer with an appropriately sized cuff. The diagnosis of $\mathrm{OH}$ was defined as a drop of at least $20 \mathrm{mmHg}$ in systolic blood pressure and/or $10 \mathrm{mmHg}$ in diastolic blood pressure upon the change in position (8). For the evaluation of walking speed, muscle strength and muscle mass, $4 \mathrm{~m}$ walking test, handgrip test and bioimpedance, respectively, were performed for each patient. Handgrip test was measured by a JAMAR branded hand dynamometer, and bioimpedance was established using TANITA scales (MC-780 U Multi Frequency Segmental Body Composition). Slow walking speed was categorized as $<0.8 \mathrm{~m} / \mathrm{s}$, and low handgrip strength in women as $<16 \mathrm{~kg}$ and in males as $<27 \mathrm{~kg}(9)$. A muscle mass index score of $<8.87 \mathrm{~kg} / \mathrm{m}^{2}$ for males and of $<6.42 \mathrm{~kg} / \mathrm{m}^{2}$ for females was regarded as low muscle mass (9). The diagnosis of sarcopenia was identified according to revised European consensus on definition and diagnosis (EWGSOP) criteria (10). The frailty was measured by Fried's physical frailty scale (11). All patients underwent a CGA, including a mini-mental state examination (MMSE), Tinetti performance-oriented mobility assessment (POMA), Barthel activities of daily living index (BADLs), Lawton-Brody instrumental activities of daily living (IADLs) (12). To perform the Up and Go test, the patient is timed while they rise from an arm chair (approximate seat height $46 \mathrm{~cm}$ ), walk at a comfortable and safe pace to a line on the floor three meters away, turn and walk back to the chair and sit down again (13).

\section{Laboratory Findings}

Specific laboratory tests were performed to evaluate the biochemical, metabolic, and nutritional status of the patients. Thus, a complete blood count, kidney and liver function, cholesterol levels, thyroidstimulating hormone (TSH), HbAlc, vitamin $\mathrm{D}$, vitamin B12, and folic acid levels were obtained for laboratory records. All these biochemical tests were performed on a Diagnostic Modular Systems autoanalyzer (Roche E170 and P-800, Roche Diagnostics, Germany). Serum 25-Hydroxyvitamin D (25$\mathrm{OHD})$ was measured with radioimmunoassay.

\section{Nutritional Status}

Nutritional status was determined by mininutritional assessment-short form (MNA-SF). The patients were divided into three groups according to their MNA-SF scores: malnourished (0-7 points), malnutrition-risk («at-risk», 8-11 points), or well-nourished (12-14 points) (6). The body mass index (BMI) of the patients was calculated by using the body weight $(\mathrm{kg})$ and the body height $(\mathrm{cm})$.

\section{Statistical Analysis}

Continuous variables were presented as means \pm standard deviation (SD) and were evaluated by the Kolmogorov-Smirnov test for normal distribution. Because all of the continuous variables were of non-normal distribution, they were evaluated with the Mann-Whitney U test. Differences between 
categorical variables were evaluated by the Chi-square and Fisher's exact Chi-square tests. Binary logistic regression analysis was performed for the relationship between wellnourished and malnutrition/malnutrition-risk groups according to age and gender. A probability $<0.05$ was considered significant. All statistical analyses were performed using the SPSS 22.0 (SPSS Inc.) package program.

\section{Ethical Issue}

The study was carried out with the permission of the Ethics Committee of Dokuz Eylul University (Permission granted: 24.11.201 Decision no: 2016/30-06). The required number of samples was calculated to be at least 390 patients with an acceptable error of $5 \%$ and a $95 \%$ confidence level (14).

\section{Results}

Total 460 patients of mean age was $77.75 \pm 8.12$, and $64.5 \%$ were female. The frequencies of malnutrition, malnutrition-risk, and well-nourished group were $14.1 \%, 30.6 \%$, and $55.3 \%$, respectively. Age and education year were statistically more different in the well-nourished group than the malnutrition and malnutrition-risk groups $(\mathrm{p}<0.05)$. Comorbidities other than cerebrovascular disease were similar between groups $(\mathrm{p}>0.05)$. The rates of falls, UI, insomnia, dementia, orthostatic hypotension, sarcopenia, frailty and polypharmacy were higher in malnutrition and malnutrition-risk groups than the normal nutritional status group $(\mathrm{p}<0.05)$. The frequency of depression was higher in the malnutrition group than the well-nourished group $(\mathrm{p}<0.05)$ (Table 1).

Table 1. Comparison of the frequencies of demographic characteristics, comorbidities, and geriatric syndromes according to nutritional status

\begin{tabular}{|c|c|c|c|c|c|c|}
\hline & $\begin{array}{l}\text { Malnutrition } \\
\text { Group } \\
n=65\end{array}$ & $\begin{array}{l}\text { Malnutrition- } \\
\text { Risk } \\
\text { Group } \\
\text { n=141 }\end{array}$ & $\begin{array}{l}\text { Well- } \\
\text { nourished } \\
\text { Group } \\
\text { n=254 }\end{array}$ & $\begin{array}{l}\text { p1 } \\
\text { value }\end{array}$ & $\begin{array}{l}\text { p2 } \\
\text { value }\end{array}$ & $\begin{array}{l}\text { p3 } \\
\text { value }\end{array}$ \\
\hline \multicolumn{7}{|c|}{ DEMOGRAPHIC FEATURES } \\
\hline Age & $82.82 \pm 7.73$ & $82.64 \pm 7.82$ & $77.90 \pm 7.27$ & $<0.001$ & $<0.001$ & 0.897 \\
\hline Sex (female; \%) & 70.7 & 63.5 & 64.2 & 0.422 & 0.879 & 0.381 \\
\hline Education Year & $5.38 \pm 3.72$ & $6.13 \pm 4.89$ & $8.78 \pm 4.49$ & $<0.001$ & $<0.001$ & 0.517 \\
\hline BMI & $22.91 \pm 5.72$ & $25.53 \pm 4.18$ & $27.89 \pm 4.11$ & $<0.001$ & $<0.001$ & 0.024 \\
\hline \multicolumn{7}{|l|}{ COMORBIDITIES (\%) } \\
\hline Hypertension & 61.5 & 64.4 & 64.2 & 0.748 & 0.969 & 0.736 \\
\hline Coronary Artery Disease & 17.9 & 17.5 & 16.1 & 0.768 & 0.699 & 0.949 \\
\hline Congestive Heart Disease & 5.1 & 6.8 & 4.1 & 0.776 & 0.243 & 0.705 \\
\hline Peripheral Artery Disease & 3.6 & 4.5 & 3.3 & 0.918 & 0.213 & 0.576 \\
\hline COPD & 10.7 & 10.3 & 6.0 & 0.125 & 0.117 & 0.644 \\
\hline Cerebrovascular Disease & 12.8 & 13.0 & 4.1 & 0.028 & 0.001 & 0.977 \\
\hline Diabetes Mellitus & 25.3 & 25.1 & 25.1 & 0.968 & 0.874 & 0.925 \\
\hline Hyperlipidemia & 10.0 & 18.6 & 22.5 & 0.073 & 0.350 & 0.189 \\
\hline \multicolumn{7}{|c|}{ GERIATRIC SYNDROMES (\%) } \\
\hline Falls & 42.5 & 35.6 & 23.4 & 0.012 & 0.008 & 0.414 \\
\hline Urinary Incontinence & 55.5 & 50.5 & 32.1 & 0.024 & $\mathbf{0 . 0 3 3}$ & 0.525 \\
\hline Insomnia & 46.2 & 44.0 & 30.1 & 0.006 & 0.004 & 0.807 \\
\hline Geriatric Depression & 42.5 & 33.3 & 25.3 & 0.026 & 0.082 & 0.272 \\
\hline Dementia & 52.5 & 43.8 & 14.8 & $<0.001$ & $<0.001$ & 0.316 \\
\hline Orthostatic Hypotension & 41.2 & 39.1 & 23.8 & 0.038 & 0.025 & 0.808 \\
\hline Sarcopenia & 57.1 & 42.0 & 16.1 & $<0.001$ & $<0.001$ & 0.291 \\
\hline Frailty & 64.3 & 48.8 & 11.0 & $<0.001$ & $<0.001$ & 0.284 \\
\hline Polypharmacy & 61.0 & 65.2 & 45.7 & 0.005 & 0.001 & 0.613 \\
\hline
\end{tabular}

Laboratory data, including the level of hemoglobin, low-density lipoprotein (LDL), $25-\mathrm{OH} \mathrm{D}$, and albumin was lower in malnutrition and malnutrition-risk groups than the well-nourished group $(\mathrm{p}<0.05)$. eGFR in the malnutrition group was lower than the other groups $(\mathrm{p}<0.05)$. When the CGA parameters were evaluated, cognitive, 
BADLs, and IADLs, gait, and balance scores were worse in malnutrition and malnutrition risk groups than the normal nutritional group $(\mathrm{p}<0.05)$ (Table 2).

Table 2. Comparison of laboratory findings and comprehensive geriatric assessment parameters according to nutritional status

\begin{tabular}{|c|c|c|c|c|c|c|}
\hline & $\begin{array}{l}\text { Malnutrition } \\
\text { Group } \\
\text { n=65 }\end{array}$ & $\begin{array}{l}\text { Malnutrisyon- } \\
\text { Risk } \\
\text { Group } \\
\text { n=141 }\end{array}$ & $\begin{array}{l}\text { Well- } \\
\text { nourished } \\
\text { Group } \\
\text { n=254 }\end{array}$ & $\begin{array}{l}\text { p1 } \\
\text { value }\end{array}$ & $\begin{array}{l}\text { p2 } \\
\text { value }\end{array}$ & $\begin{array}{l}\text { p3 } \\
\text { value }\end{array}$ \\
\hline \multicolumn{7}{|c|}{ LABORATORY FINDINGS (Median [IQR]) } \\
\hline Hemoglobin (g/dL) & $12.60[2.05]$ & $12.40[1.60]$ & $13.15[1.83]$ & 0.044 & $<0.001$ & 0.756 \\
\hline Glucose (mg/dL) & $98[18]$ & $98[36]$ & $97[24]$ & 0.445 & 0.204 & 0.994 \\
\hline LDL (mg/dL) & $124[57]$ & 122 [49] & $139[59]$ & 0.019 & 0.001 & 0.563 \\
\hline HDL (mg/dL) & $57[27]$ & $53[21]$ & $55[17]$ & 0.224 & 0.384 & 0.092 \\
\hline Tryglyceride (mg/dL) & $108[53]$ & $119[78]$ & $128[78]$ & 0.051 & 0.252 & 0.2362 \\
\hline Albumin $(g / L)$ & $3.94[0.32]$ & $4.01[0.49]$ & $4.18[0.40]$ & $<0.001$ & $<0.001$ & 0.139 \\
\hline 25(OH)D (ng/mL) & $12.40[13.54]$ & $15.5[18.24]$ & $19.08[11.63]$ & $<0.001$ & 0.011 & 0.075 \\
\hline TSH (mg/dL) & $1.23[1.38]$ & $1.23[1.06]$ & $1.17[0.79]$ & 0.921 & 0.563 & 0.779 \\
\hline Vitamine B12 (pg/mL) & $294[266]$ & $389[421]$ & $333[238]$ & 0.769 & 0.685 & 0.120 \\
\hline eGFR $\left(\mathrm{mL} / \mathrm{min} / 1.73 \mathrm{~m}^{2}\right)$ & $64[23]$ & $74[27]$ & $73[29]$ & 0.039 & 0.786 & 0.048 \\
\hline \multicolumn{7}{|c|}{ COMPREHENSIVE GERIATRIC ASSESSMENT (Median [IQR]) } \\
\hline MMSE & $21.50[8]$ & $21[11]$ & $28[6]$ & $<0.001$ & $<0.001$ & 0.633 \\
\hline POMA & $22[8]$ & $24[7]$ & $28[3]$ & $<0.001$ & $<0.001$ & 0.348 \\
\hline Up and Go Test & $14[10]$ & $15[8]$ & $10[5]$ & $<0.001$ & $<0.001$ & 0.843 \\
\hline Basic ADLs & $91[14]$ & $93.5[17]$ & $98[8]$ & $<0.001$ & $<0.001$ & 0.610 \\
\hline Instrumental ADLs & $13[13]$ & $15[12]$ & $22[5]$ & $<0.001$ & $<0.001$ & 0.082 \\
\hline \multicolumn{7}{|c|}{$\begin{array}{l}\text { 25(OH)D: 25-hydroxyvitamin D; ADLs: Activities of Daily Living; eGFR: estimated Glomerular Filtration Rate, } \\
\text { HDL: High-Density Lipoprotein; IQR: Interquartile Range; LDL: Low-Density Lipoprotein; MMSE: Mini-Menta } \\
\text { State Examination; POMA: Performance-oriented Mobility Assessment; TSH: Thyroid Stimulating Hormone p1. } \\
\text { comparisons for between malnutrition and well-nourished group; } 2 \text { 2: comparisons for between malnutrition-risk and } \\
\text { well-nourished group; } 3 \text { : comparisons for between malnutrition and malnutrition-risk group. }\end{array}$} \\
\hline
\end{tabular}

In the logistic regression analysis adjusted for age and gender, history of falls, the presence of UI, dementia, insomnia, orthostatic hypotension, sarcopenia, frailty, and geriatric depression was associated with malnutrition and malnutrition-risk compared to the wellnourished group $(\mathrm{p}<0.05)$ (Table 3$)$

Table 3. The relationship between several geriatric syndromes and nutritional status by binary logistic regression analysis

\begin{tabular}{|c|c|c|c|c|c|c|}
\hline & \multicolumn{3}{|c|}{ Malnutrition vs. Well-nourished Group } & \multicolumn{3}{|c|}{ Malnutrition-Risk vs. Well-nourished Group } \\
\hline & $\mathrm{OR}$ & $\% 95$ CI & $\mathrm{p}$ value & OR & $\% 95 \mathrm{CI}$ & $\mathrm{p}$ value \\
\hline Falls & 1.89 & $1.02-3.37$ & 0.044 & 1.48 & $0.93-2.36$ & 0.097 \\
\hline Urinary Incontinence & 1.81 & $1.07-2.85$ & 0.038 & 1.75 & $1.11-2.68$ & 0.026 \\
\hline Dementia & 6.87 & $3.13-15.08$ & $<0.001$ & 4.10 & $2.46-6.80$ & $<0.001$ \\
\hline Insomina & 1.89 & $0.90-3.95$ & 0.089 & 1.79 & $1.15-2.78$ & 0.009 \\
\hline $\begin{array}{l}\text { Orthostatic } \\
\text { Hypotension }\end{array}$ & 2.05 & $1.21-3.49$ & 0.018 & 2.01 & $1.18-3.43$ & 0.010 \\
\hline Sarcopenia & 5.17 & $1.56-17.15$ & 0.007 & 2.78 & $1.45-5.31$ & 0.002 \\
\hline Frailty & 15.82 & $3.58-69.95$ & $<0.001$ & 6.74 & $3.16-14.36$ & $<\mathbf{0 . 0 0 1}$ \\
\hline Geriatric Depression & 2.49 & $1.19-5.19$ & 0.015 & 1.69 & $1.06-2.70$ & 0.027 \\
\hline Polypharmacy & 1.49 & $0.97-2.31$ & 0.069 & 1.40 & $0.69-2.86$ & 0.349 \\
\hline
\end{tabular}

*The binominal logistic regression analysis is performed adjusted for age and gender

CI: Confidence Interval; OR: Odds Ratio 


\section{Discussion}

In this study, it is determined that the risk of malnutrition, in common with malnutrition, is associated with the presence of UI, dementia, $\mathrm{OH}$, sarcopenia, frailty, and geriatric depression regardless of age and gender.

The prevalence of malnutrition increases with age. It is $5 \%$ to $30 \%$ in elderly persons living at home (15). It is shown that the frequency of malnutrition \%14.1 in this study, and stated that this finding is compatible with the literature. In addition, the percentage of malnutrition risk in our study was observed to be approximate twice the frequency of malnutrition. The risk of malnutrition, which is more common, may have negative consequences in the future, and the importance of early nutritional improvements should be emphasized in elderly individuals.

Sarcopenia is a progressive and generalized skeletal muscle disorder associated with an increased likelihood of adverse outcomes, including falls, fractures, physical disability, and mortality (10). It is known that one of the most important risk factors in sarcopenia, which is an inevitable part of aging, is the decrease in the body's ability to synthesize protein and insufficient calorie intake (16). Thus, malnutrition contributes to the development of sarcopenia. Nutritional practices in nutritional screening and approach to malnutrition also play an essential role in the management of sarcopenia (17). Besides, malnutrition can lead to sarcopenia by directly causing muscle weakness, and it may also be associated with sarcopenia through common mechanisms such as inflammation and oxidative stress (18). Frailty, a clinical state characterized by a decrease of an individual's homeostatic reserves and is responsible for enhanced vulnerability to endogenous and exogenous stressors, is a crucial geriatric syndrome (19). According to the Fried frailty scale, the diagnosis is made based on muscle weakness, reduced mobility, fatigue, weight loss, and resistance (11). Thus, it is easily understood that it can overlap with malnutrition and sarcopenia. Boulos et al. highlighted the significant association between malnutrition and frailty, indicating that these constructs share common sociodemographic, physical, and cognitive risk factors (20). As malnutrition and frailty share risk factors, it is anticipated that many individuals will present with both frailty and malnutrition (21). In our study, we emphasized that malnutrition and malnutrition risk was related to frailty and sarcopenia. In terms of these three geriatric syndromes whose frequency increases with age, we showed the relationship between nutritional status and sarcopenia and frailty regardless of age. It probably suggests that it may have other unknown common mechanisms, and further research is needed in this area.

Compared to cognitively healthy elderly individuals, weight loss occurs more frequently in older patients with dementia (22). Moreover, weight loss may be the first finding in patients diagnosed with dementia (23). The mechanism of weight loss in patients with dementia is complex, multifactorial, and partially understood (24). In some studies, the neurodegenerative process in specific brain regions, inflammation, and genetic factors in patients with Alzheimer's disease may be associated with nutritional changes (23). It is also stated that it may be related to decreased appetite secondary to brain atrophy and deterioration in eating behavior (23). In addition, malnutrition may develop due to insufficient shopping, food storage, and cooking in the early stages of dementia (25). Our study emphasizes that the risk of dementia may increase in patients with nutritional problems, the development of dietary strategies in the early period, and the importance of nutritional screening in this group of patients (26). Also, ADLs are affected in patients with malnutrition risk, which may partially explain this condition. Similarly, depression can be presented by weight loss and decreased appetite (27). Affected ADLs due to depressive symptoms and general moodiness may also contribute to malnutrition (28). Besides, studies have shown a strong correlation between MNA score and geriatric depression scales (26). As we have shown, it 
is crucial to question the elderly in terms of depression within the scope of CGA during nutritional screening.

Fall-related injury emerges as an important cause of morbidity and mortality in the elderly (29). Damages caused by falling lead to an increase in nursing home admission and dependence (30). The results of studies on nutritional status and fall risk in the literature are contradictory. However, a systematic review showed that an increased risk of falling was associated with muscle weakness and impaired movement coordination (31). In our study, parallel to sarcopenia, frailty, and low BMI, in addition to an increase in the risk of falling, impaired balance and gait tests were also found in the malnourished older people. $\mathrm{OH}$ is also known to be associated with the risk of falling and impaired balance (32). The relationship between $\mathrm{OH}$ and malnutrition is little known in the literature. In a recent study, it has been shown that malnutrition may be associated with systolic $\mathrm{OH}$ measured using the Head-up Tilt table test, and it was stated that the possible mechanism in this relationship could be an increase in venous pooling secondary to muscle weakness in the lower extremity associated with malnutrition (33). In our study, it has been shown that the risk of malnutrition and malnutrition might be related to $\mathrm{OH}$, and it is vital in that this relationship is independent of age and may also be demonstrated by using the active standing test, which is easier to use in the clinic. Besides, it is shown that the risk of malnutrition is not associated with falls but is associated with $\mathrm{OH}$ that may increase the falling risk.

$\mathrm{UI}$ is a geriatric syndrome that is quite common in the elderly, and its frequency increases with age (34). Studies have shown that UI is associated with malnutrition, dementia, and reduced mobility in older adults (35). The risk of UI may increase due to a decrease in the size and contraction of the bladder muscle sphincter associated with malnutrition. In addition, sarcopenia might lead to pelvic floor muscle atrophy (36). Malnutrition may contribute the urinary incontinence as one of the factors affecting the development of sarcopenia. Our study should also underline that the risk of UI may have increased in individuals with even malnutrition risk. Although there is not enough research in the literature showing the relationship between nutritional status and insomnia, a recent study showed that there might be a relationship between insomnia and malnutrition (37). It has been stated in studies that this relationship may be related to the effect of circadian rhythm secondary to malnutrition, decrease in melatonin secretion, and increase in white matter hyperintensity in specific regions of the brain (37). In addition, it is thought that the frequent incidence of sleep disorders in dementia and depression may partially support this relationship. In our study, it is shown that the risk of malnutrition, not malnutrition, is related to insomnia.

Polypharmacy is a common problem in older adults that can lead to nutritional disorders with the effects such as dyspepsia and anorexia $(38,39)$. The relationship between polypharmacy and malnutrition is quite complex in the literature (39). Although the frequency of polypharmacy was higher in individuals with malnutrition and at risk of malnutrition in our study, this relationship disappeared when age and sex adjusted. This can be explained by significant contributions of age-related factors to nutritional disorders including anorexia of aging, decreased gastrointestinal motility and secretion.

The present study has several strengths. First, malnutrition and malnutrition risk are evaluated in detail in terms of geriatric syndrome and CGA parameters. Second, the sample size is sufficient for analysis. Third, the relationship between malnutrition and other geriatric syndromes is demonstrated regardless of age and gender. There are some limitations in our study. The first is that it is a cross-sectional and retrospective study. The second is that UI subtypes are not evaluated.

\section{Conclusion}

The risk of malnutrition is as important as malnutrition in geriatric practice. Screening of patients using MNA-SF may alert health care professionals for not only malnutrition, but also the other geriatric syndromes. Therefore, nutritional evaluation must be included in the 
assessment of older adults, and necessary interventions should be made to optimize the

\section{REFERENCES}

1. Ellis G,Whitehead MA, Robinson D, et al. Comprehensi ve geriatric assessment for older adults admitted to hospital: meta-analysis of randomised controlled trials. BMJ. 2011; 343: d6553.

2. Garrard JW, Cox NJ, Dodds RM, et al. Comprehensive geriatric assessment in primary care: a systematic review. Aging Clin Exp Res. 2020; 32: 197-205.

3. Johnson LE, Sullivan DH. Malnutrition in older adults. 2016, Brocklehurst's textbook of geriatric medicine and gerontology (Eight Edition) Philadelphia: Elsevier.

4. Ahmed T, Haboubi N. Assessment and management of nutrition in older people and its importance to health. Clin Interv Aging. 2010; 5: 207-16.

5. Söderström L, Rosenblad A, Adolfsson ET, et al. Malnutrition is associated with increased mortality in older adults regardless of the cause of death. Br J Nutr. 2017; 117: 532-40.

6. Vellas B, Guigoz Y, Garry PJ, et al. The mini nutritional assessment (MNA) and its use in grading the nutritional state of elderly patients. Nutrition. 1999; 15: $116 \mathrm{e} 22$.

7. Saka B, Kaya O, Ozturk GB, et al. Malnutrition in the elderly and its relationship with other geriatric syndromes. Clin Nutr. 2010; 29: 745-8.

8. Consensus statement on the definition of orthostatic hypotension, pure autonomic failure, and multiple system atrophy. The Consensus Committee of the American Autonomic Society and the American Academy of Neurology. Neurology. 1996; 46: 1470.

9. Ates Bulut E, Soysal P, Dokuzlar O, et al. Validation of population-based cutoffs for low muscle mass and strength in a population of Turkish elderly adults. Aging Clin Exp Res. 2020;32:1749-55.

10. Cruz-Jentoft AJ, Bahat G, Bauer J, et al. Sarcopenia: revised European consensus on definition and diagnosis. Age Ageing. 2019; 48: 16-31.

11. Fried LP, Tangen CM, Walston J, et al. Frailty in older adults: evidence for a phenotype. J Gerontol A Biol Sci Med Sci 2001; 56: 146-56.

12. Unutmaz GD, Soysal P, Tuven B, et al. Costs of medication in older patients: before and after comprehensive geriatric assessment. Clin Interv Aging. 2018; 13: 607-13.

13. Podsiadlo D, Richardson S. The timed "Up \& Go": a test of basic functional mobility for frail elderly persons. J Am Geriatr Soc. 1991;39:142-8.

14. Kaiser MJ, Bauer JM, Rämsch C, et al. Frequency of malnutrition in older adults: a multinational perspective using the mini nutritional assessment. $\mathrm{J} \mathrm{Am}$ Geriatr Soc. 2010; 58: 1734-8.

15. Guyonnet S, Rolland Y. Screening for malnutrition in older people. Clin Geriatr Med. 2015; 31: 429-37.

16. Marcell TJ. Sarcopenia: causes, consequences, and preventions. J Gerontol A Biol Sci Med Sci. 2003; 58: 911-6.

17. Dhillon RJ, Hasni S. Pathogenesis and management of sarcopenia. Clin Geriatr Med. 2017; 33: 17-26. nutritional status.

18. Agarwal E, Miller M, Yaxley A, et al. Malnutrition in the elderly: a narrative review. Maturitas. 2013; 76: 296-302.

19. Cesari M, Calvani R, Marzetti E. Frailty in older persons. Clin Geriatr Med. 2017; 33: 293-303.

20. Boulos C, Salameh P, Barberger-Gateau P. Malnutrition and frailty in community dwelling older adults living in a rural setting. Clin Nutr. 2016; 35: 138-43.

21. Laur CV, McNicholl T, Valaitis R, et al. Malnutrition or frailty? Overlap and evidence gaps in the diagnosis and treatment of frailty and malnutrition. Appl Physiol Nutr Metab. 2017; 42: 449-58.

22. Gillette Guyonnet S, Abellan Van Kan G, Alix E, et al. International Academy on Nutrition and Aging Expert Group. IANA (International Academy on Nutrition and Aging) Expert Group: weight loss and Alzheimer's disease. J Nutr Health Aging. 2007; 11: 38-48.

23. Volkert D, Chourdakis M, Faxen-Irving G, et al. ESPEN guidelines on nutrition in dementia. Clin Nutr. 2015; 34: 1052-73

24. Smith KL, Greenwood CE. Weight loss and nutritional considerations in Alzheimer disease. $J$ Nutr Elder. 2008; 27: 381-403.

25. Chang CC, Roberts BL. Feeding difficulty in older adults with dementia. J Clin Nurs. 2008; 17: 2266-74.

26. Smoliner $\mathrm{C}$, Norman $\mathrm{K}$, Wagner $\mathrm{KH}$, et al. Malnutrition and depression in the institutionalised elderly. Br J Nutr. 2009; 102: 1663-7.

27. Thomas P, Hazif-Thomas C, Clement JP. Influence of antidepressant therapies on weight and appetite in the elderly. J Nutr Health Aging. 2003; 7: 166-70.

28. Abrams RC, Teresi JA, Butin DN. Depression in nursing home residents. Clin Geriatr Med. 1992; 8: 309-22.

29. Zhao $\mathrm{R}, \mathrm{Bu} \mathrm{W}$, Chen $\mathrm{X}$. The efficacy and safety of exercise for prevention of fall-related injuries in older people with different health conditions, and differing intervention protocols: a meta-analysis of randomized controlled trials. BMC Geriatr. 2019; 19: 341

30. Isenring E, Baker J, Kerr G. Malnutrition and falls risk in community-dwelling older adults. J Nutr Health Aging 2013; 17: 277-9.

31. Geinoz G, Rapin $\mathrm{CH}$, Rizzoli R, et al. Relationship between bone mineral density and dietary intakes in the elderly. Osteoporos Int. 1993; 3: 242-8.

32. Mol A, Bui Hoang PTS, Sharmin S, et al. Orthostatic hypotension and falls in older adults: a systematic review and meta-analysis. J Am Med Dir Assoc. 2019; 20: 589-97.

33. Kocyigit SE, Soysal P, Ates Bulut E, et al. Malnutrition and malnutrition risk can be associated with systolic orthostatic hypotension in older adults. $J$ Nutr Health Aging. 2018; 22: 928-33.

34. Irwin DE, Milsom I, Hunskaar S, et al. Populationbased survey of urinary incontinence, overactive bladder, and other lower urinary tract symptoms in five countries: results of the EPIC study. Eur Urol. 2006; 50: 1306-14. 
35. Miu DK, Lau S, Szeto SS. Etiology and predictors of urinary incontinence and its effect on quality of life. Geriatr Gerontol Int. 2010; 10: 177-82.

36. Parker-Autry C, Houston DK, Rushing J, Richter HE, Subak L, Kanaya AM, Kritchevsky SB. Characterizing the Functional Decline of Older Women With Incident Urinary Incontinence. Obstet Gynecol. 2017;130(5):1025-1032.

37. Soysal P, Smith L, Dokuzlar O, et al. Relationship between nutritional status and insomnia severity in older adults. J Am Med Dir Assoc .2019; 20: 1593-8.

38. Bytzer P. Dyspepsia as an adverse effect of drugs. Best Pract Res Clin Gastroenterol. 2010;24(2):109-20.

39. Zadak Z, Hyspler R, Ticha A, et al. Polypharmacy and malnutrition. Curr Opin Clin Nutr Metab Care. 2013;16:50-5. 